\title{
Perambulation and Performance in Early Modern Festive Culture
}

\begin{abstract}
This essay examines the performative aspect of observances and festivities associated with Rogationtide, or 'perambulation day', in early modern England. After considering pre-and post-Reformation Rogationtide traditions, it identifies how these occasions were an opportunity for communities and parishes to reflect upon and consolidate local boundaries and identities. It also explores how documentary evidence for perambulations broadens critical understandings of the mimetic, musical, and festive activities recorded in the Records of Early English Drama (REED) project, posing methodological questions about using performance as well as mimesis as a characteristic determining a record's inclusion in a REED collection.
\end{abstract}

Perambulation day — or, more accurately, a perambulation day — is one of several names used widely from the mid-sixteenth century onwards to denote the Monday, Tuesday, and Wednesday of Rogation week leading up to Ascension Thursday (celebrated forty days after Easter Sunday). This occasion occupied a central place in the festive and performative culture of Tudor and Stuart England, of which the dramatic and musical activities recorded and reconstructed in the edited collections of the Records of Early English Drama (REED) project are a part. This essay intends to draw attention to the performative elements of pre- and post-Reformation Rogationtide and to highlight the value of assembling and evaluating records of festivities connected with this occasion in relation to those for more 'canonical' forms of dramatic, ceremonial, and minstrel activity. In doing so it attempts to make a case for contextualizing REED records in relation to those that fall outside of editors' typical selection criteria.

Both before and after the Reformation Rogationtide served as a vital occasion for the communal performance of parish identity, cohesion, and the preservation of territorial boundaries. Rogationtide was a major liturgical feast introduced into

Matthew Woodcock (matthew.woodcock@uea.ac.uk) is professor of medieval and early modern literature in the school of Literature, Drama and Creative Writing at the University of East Anglia. 
the English church in the year $747 .{ }^{1}$ Second in importance only to Easter in the Anglo-Saxon liturgical calendar, it would remain, in various modified forms, a popular occasion for religious observance and communal festivity until long after the Reformation. Its origins are thought to lie in parish ceremonies asking from Latin rogare - for God's protection and favourable weather during a period when crops were growing in late spring. Nathan J. Ristuccia proposed recently, however, that early celebrations of the feast of Rogationtide were rooted in an urban context, involving public processions and displaying of relics within civic communities. ${ }^{2}$ Prior to the Reformation, Rogation days were typically marked by processions undertaken by members of the congregation around the boundaries of a parish. This was accompanied by the bearing of crosses and banners, ringing of handbells, praying at wayside crosses, and the singing of the litany of saints. ${ }^{3}$ The various activities involved in celebrating Rogationtide came to shape the different ways in which contemporary records referred to this occasion: as Cross days, banner days, procession days, or ganging days (from Old English gangdagas - the days on which one 'goes' processing). ${ }^{4}$ Thirteenth-century hagiographic collections, the Golden Legend and South English Legendary, offer short accounts of Rogationtide's origins and describe how it was observed. ${ }^{5}$ They mention too the appearance of dragon banners used in these events as an emblem of hellish elements that the processions were intended to expel. We can trace comparable celebrations of Rogationtide in many extant churchwardens' accounts up until the mid-1540s, as evidenced by payments to men and boys for bell-ringing, carrying the cross, or bearing and maintaining banners that were often richly painted and adorned with small bells. ${ }^{6}$ Early sixteenth-century parishioners of St Edmund's, Salisbury, for example, processed with no fewer than seventeen banners depicting saints and scenes from Christ's life. ${ }^{7}$

Such processions performed several functions: as well as serving as a ritual means of protecting the parish and its property, they also emphasized communal self-definition and the identification of a parish to itself as a corporate body and in relation to neighbouring parishes. Rogation processions had also long served as important rituals of parish demarcation, the limits and boundaries of parish territory being marked, affirmed, and committed to memory through the act of perambulating the perimeter of this territory and 'beating the bounds' with rods. ${ }^{8}$ This latter practice gives us the term by which Rogation observances are still best known today. This demarcation and performance of a ritual mnemonic involved the actual beating of marker points - usually stones, trees, or posts and occasionally the beating of junior members of the processing congregation at particular points to keep younger generations mindful of territorial limits. 
Duckings or nipping of ears were also useful aides-memoire. ${ }^{9}$ The visibility of such occasions was especially significant: 'the bounds had to be beaten in plain sight of everyone, before the eyes of this community and of the communities of its brothers and rivals'. ${ }^{10}$ Indeed, as intra-community identity was fostered and celebrated, disputes between neighbouring parishes over competing memories of where boundaries lay could also occur. ${ }^{11}$

Rogationtide was at heart, however, an occasion for reconciliation and consolidation: the resolving of boundaries and the mending of fences, both figurative and actual. Writing in the 1630 s of the country parson's duty to be accommodating of 'old customs', clergyman and poet George Herbert identified 'neighbourly accompanying [of] one another, and reconciling of differences at that time' as one of several benefits that (reformed) Rogationtide observances brought to a community. ${ }^{12}$ Although part of the post-Easter penitential phase of the Christian calendar and thus a period of fasting, pre-Reformation Rogation processions were traditionally a time for parish communities to enjoy food and drink together, with the more wealthy providing for poorer members. ${ }^{13}$ On the basis of extant evidence, Rogationtide was not an occasion for scripted drama, unlike Corpus Christi or Whitsuntide, but it was a period in which different forms of 'play' or 'game' - following Lawrence M. Clopper's taxonomy — could be enacted to foster a sense of community. ${ }^{14}$

We also have ample evidence of Rogation festivities and beating of bounds taking place in urban parishes; the emphasis here was upon community identity, cohesion, and mapping, rather than crop-growing. One of the most elaborate examples of these observances comes from fifteenth-century Beverley, in the East Riding of Yorkshire. ${ }^{15}$ For Rogation Monday the town's craft guilds sat in specially constructed wooden castles to watch the procession of the shrine of St John of Beverley through — rather than around - the town. Records also provide evidence of city-based Rogation processions in Canterbury, Oxford, Salisbury, Durham, and London. ${ }^{16}$

As one might imagine, early Protestant reformers objected to many elements of Rogation processions. In 1519 Martin Luther attacked Rogationtide for the moral abuses (drunkenness, licentiousness) that had routinely become attendant upon the occasion, and for elements of its original function that seemed perilously close to extra-scriptural superstition and fertility rites. ${ }^{17}$ For Luther, Rogation epitomized the rituals and culture of the pre-reformed church that valorized works over prayer. In England during the 1530s and 40s, reformers such as William Tyndale and Richard Taverner attacked both the superstitious and unruly aspects of Rogationtide activities. 'Rogyng week', as one Elizabethan minister called it 
disdainfully, continued to attract periodic criticism and condemnation throughout the sixteenth and seventeenth centuries. ${ }^{18}$

Nevertheless, Rogation observances survived the Edwardian reforms of 1547, and the 1559 Royal Injunctions went on to clearly identify Rogationtide's place within the reformed calendar. The eighteenth and nineteenth injunctions, addressing processions and reform of the litany, kept one of the fundamental practices at the heart of Rogationtide and prescribed the form that these should take:

[18] But yet for retaining of the perambulation of the circuits of parishes, they shall once in the year at the time accustomed, with the curate and the substantial men of the parish, walk about their parishes as they were accustomed, and at their return to the church make their Common Prayers.

[19] Provided, that the curate in their said common perambulations used heretofore in the days of Rogations, at certain convenient places shall admonish the people to give thanks to God, in the beholding of God's benefits, for the increase and abundance of his fruits upon the face of the earth, with the saying of the ciii Psalm, Benedic, anima mea, etc., or such like. At which time also the same minister shall inculcate these or such sentences, 'Cursed be he which translateth the bounds and doles of his neighbour', or such other order of prayers as shall be hereafter appointed. ${ }^{19}$

All ceremonial and sacramental elements (bells, banners, crosses, surplices) were removed. Processions were recast explicitly as perambulations, as Edmund Grindal, bishop of London stressed when writing to fellow ministers in $1560 .{ }^{20}$ Subsequent injunctions of 1571 repeated earlier definitions and directed that Psalm 104 as well as 103 should be read. ${ }^{21}$ The emphasis on community was retained; the 'they' in the first quoted line of the eighteenth injunction refers to all parishioners. Increasingly, however, only select representatives of the community - just the 'substantial men of the parish' - undertook perambulations, as an attempt to curtail the potential for unlicensed, unruly activity. Several bishops' injunctions explicitly excluded women from perambulations. ${ }^{22}$ Episcopal visitations were tasked specifically with recording where ministers and/or churchwardens retained vestiges of former practices or indeed where they had failed in their duty to conduct perambulations. ${ }^{23}$ The 1597 visitation for the archdeaconry of Norwich noted that the perambulation of St Andrew's parish had not been gone in seven years and that at St George's Colegate one of the churchwardens actively 'wold not suffer yt'. ${ }^{24}$ Provision for the perennially popular hospitality 
post-perambulation is never mentioned in official injunctions, though evidence from numerous churchwardens' accounts attests that it was still a vital part of the occasion.

Ample evidence indicates that prescriptions regarding practice, personnel, and provisioning made post-Reformation perambulation day no less communal, festive, or potentially controversial. Records from post-1540 Norwich, for example, make it clear that perambulations remained an opportunity for communal enjoyment of cakes, ale, and occasionally other luxuries such as sugar — for holiday and celebration, rather than simply devotion. Six of the eight extant churchwardens' accounts from Norwich's thirty-four parishes for the Tudor and Stuart periods record perambulation breakfasts and dinners. ${ }^{25}$ Nothing in surviving churchwardens' accounts enables us to add any specific local details - or evidence of musical or mimetic activity - to what we can envisage took place as prescribed by the 1559 and subsequent injunctions.

So where might records relating to Rogationtide and perambulation days fit within REED collections? How should REED editors incorporate references to a unique survival from pre-Reformation festive culture: 'the sole Anglican remnant of the ubiquitous processions of medieval England'?26 Editorial protocol and practice have generally meant that Rogationtide, due to its earlier, fundamentally liturgical, and non-mimetic nature has not featured in REED collections, which, in order to limit the kinds of activities and events constituting a valid 'record', as a working principle exclude anything with a basis in liturgical or ceremonial observance. Of REED's twenty-eight published collections (including the three born-digital collections, Staffordshire, Berkshire, and Hampshire), only three mention records featuring Rogationtide festivities. ${ }^{27}$ Perambulations tend to warrant mention or generate a REED record for several particular reasons: if there is mimetic, musical, or more generally festive activity; when something goes wrong or there is some form of transgression and/or censure; and if there is something otherwise exceptional about the occasion or the response it induced at the time. As is so often the situation encountered by REED editors, if an event or occasion neither produced nor required parish, guild, or civic expenditure, or did not invite any kind of legal intervention, it could well leave very little documentary trace. Extant REED collections include several references to noteworthy Rogationtide festivities fitting into the third category identified above. These range from a perambulation in early 1520 s Lincolnshire taking the form of a mock-muster; via a mock bullbaiting in Wells on Rogation Sunday 1607; to passing mentions from earlier seventeenth-century Somerset of patronal feasts that appear in the records as 'revel' days occasionally taking place at this time of year, which may or may not 
have included entertainments. ${ }^{28}$ Inclusion in each case is warranted by accompanying mimetic or musical activity. More elaborate ridings of local boundaries took place in Carlisle in Cumberland on Ascension Thursday between 1593 and 1635, involving the mayor and brethren of the corporation and accompanying waits, musicians, a fool, and a juggler. ${ }^{29}$ There are also references to civic perambulations and ridings, distinct from Rogationtide observances, in the Devon, Norwich 1540-1642, and Dorset/Cornwall volumes. ${ }^{30}$

In mid-Tudor Norwich there existed a separate tradition of marking the boundaries of the whole city, again distinct from Rogation observances, conducted by the mayor, aldermen, and waits (the city's minstrels). References to payments relating to the civic perambulation, described as 'Owte Riding' in early accounts, date from 1559-60. ${ }^{31}$ The entry in the chamberlains' accounts from 21 June 1591 offers some indication of the size and expense involved:

Payed to Robert Golthorpp the xxj daye of Iune for the dynner of certeyne Aldermen, the Chambleynes Councellors the olde $\&$ new ffestmakers $\&$ diuerse other that ded ryde the perambulacion with the trumpiter charge $\&$ the waytes $\&$ the charge of one that ryd before to laye ope the waye iij li. xiij s. ${ }^{32}$

The civic perambulation involved marking out the city boundaries in their entirety. This was some fourteen miles and entailed marking not simply the perimeter of the city walls, but following the extra-mural boundaries of the county of the city of Norwich, which were greatly expanded in $1556 .{ }^{33}$ The greater distance, combined with simple social decorum, necessitated the use of horses. Indeed, it is payments made to several of the city waits for horse hire, rather than musical services or perambulating activities, that prompted editorial attention in the Norwich REED collection.

Documentary evidence of transgressive behaviour is a welcome gift for a REED editor, and we find many examples of where perambulation days were purposively used for misrule or confrontation. ${ }^{34}$ A Star Chamber case from 1619 relating to the village of Old Buckenham, Norfolk - the case of Cock vs Jolly — describes how a parish perambulation was used as pretext for an unlawful assembly that gathered to tear down fences enclosing common pasture ground. In May 1617 Robert Jolly and his fellows made out that they were headed to George Cock's property, part of the traditional perambulation route, but, arming themselves and singing 'vncivill songes and Tunes', they destroyed Cock's fences before retiring to the alehouse to celebrate their achievements: 
And when they were Come to the said messuage then in stead of singing $\lceil$ of $\rceil$ Psalme and reading of parte of the new Testament, there as vsyally they had done in former tymes past which vsed to goe the perambulacion of the said parishe They the said persons being soe assembled as aforesaid and being weaponed most malitiously and in disgracefull manner did singe, tooke out new Oysters, new Mackerels, and such like vncivill songes and Tunes and then and there vnlawfully Riottously and with force and armes they with mollspades Hatchettes Axes Brushehookes and staves did breake beate downe throwe downe and Cutt in sunder the said ffence of Rayles and pales formerly sett vpp by the said George Cocke as aforesaid And the servantes of the said George Cocke which were within the said messuage perceiving the Riottous Carriage and demeanour of the said persons and the said servantes fearing they might receive some hurte by or from the said Ryottous persons There vppon the said servantes durst not goe out of the said messuage to offer vnto them the said Riottous persons that which they had provided by the Comaundement of the said George Cocke theire Master And after that the said Riottous persons had vnlawfully and Riottously broken downe the said Rayles and pales as aforesaid then they forthwith went vnto an Alehowse in the said Towne of ould Buckenham and did make themselues merry and Iested and sported at that which they had done. ${ }^{35}$

Neither prescribed boundaries nor the more decorous communal traditions of perambulation day were observed that year.

How else might REED editors and social historians treat references to Rogationtide festivities and civic perambulations? One way could be to view perambulation days in relation to continuations of pre-Reformation festive practices, as per the argument constructed by Muriel McClendon concerning the replacement of religious with civic ceremonies and commemorations in the mid-sixteenth century. ${ }^{36}$ In mid-Tudor Norwich, for example, records from May 1541 reveal that the city corporation agreed to establish a new procession for Rogation Monday that progressed from the cathedral to the newly acquired hall at Blackfriars (now St Andrew's Hall), and concluded with sermons paid for by the city. 37 Civicfunded sermons for Rogation Monday and Tuesday feature regularly in Norwich's chamberlains' accounts well into the seventeenth century. The changed processional route placed emphasis on a new civic focal point for what Carole Rawcliffe called 'the physical and spatial cohesion of the body politic'. ${ }^{38}$ This shift anticipated how the corporation would appropriate religious ritual and festive occasions several decades later. When the Elizabethan injunctions retained perambulations but abolished all other processions, Norwich's increasingly elaborate outriding festivities apparently came to perform a similar reflexive ceremonial role to that 
previously played by the city's elaborate Corpus Christi processions, for which we possess records dating until 1557-58. ${ }^{39}$ Miri Rubin has discussed the important role Corpus Christi processions played in demarcating and memorializing territorial boundaries, which had also always been (as discussed earlier) an integral part of Rogationtide perambulations, but evidently more work needs to be done in investigating the part that perambulations - and indeed other processional traditions - played in the afterlife of Corpus Christi. ${ }^{40} \mathrm{Mid}$-sixteenth-century Norwich retained, though repurposed with an emphasis on city and state, a number of pre-Reformation festive traditions previously connected with religious sites and guilds, including the festivities produced by the restructured Company of St George. ${ }^{41}$ Norwich's extended civic perambulation may be another example of a post-Reformation adaptation of an earlier festive tradition.

In the final part of this essay I would like to propose that editors and historians might approach perambulation days and Rogation observances as occasions that in and of themselves represented a form of public performance of parish and civic identities. Scholars once argued that a combination of enclosures and the so-called early modern reformation of custom spelled the end for perambulations and the occasion they provided for celebrations and festivity. ${ }^{42}$ But as social historians have continued to demonstrate, Rogationtide and the beating of bounds was marked throughout the Stuart period and even saw a revival in the earlier seventeenth century. ${ }^{43}$ Reformers identified early on the valuable role perambulations played in publicly affirming parish identity. The 1563 homily for Rogationtide explicitly mentions that this was an occasion to 'consider the old ancient bound and limits belonging to our own township'. 44 The cartographic function of a perambulation also became particularly important following the Poor Law Acts of 1597 and 1601, which placed all responsibility for poor relief onto the parish. ${ }^{45}$ Knowing where boundaries lay, and who was in and out, took on renewed significance, as did Rogationtide's traditional emphasis on communal charity. Manchester's minister enjoined parishioners 'both rich and poor' to accompany him on a six-day perambulation in 1597 'if they desired the preservation of love and their parish rights and liberties'. 46 As Andy Wood has discussed, Rogationtide observances played an important role in making visible the very concept of community. Such observances were an occasion for displaying a village or parish to itself, and for connecting communal memory and collective identity with a particular location. Custom itself became performative as the community were annually reminded of their roles as members of a community: custom was something heard (in the reading of psalms); something enacted (through marking of boundaries); and something felt (in the form of both welcome sustenance and, for 
some, occasional beatings). ${ }^{47}$ Consciously distanced from liturgical processions by Grindal and others, perambulation day thus retained many elements of secular ritual that had long made it a valued and valuable occasion for parish and civic communities — both rural and urban - to actively stage a reaffirmation and celebration of communal identity.

REED editors by convention use the concept of mimetic activity as the marker that qualifies a record for inclusion within the main body of a collection. This practice looks back to a working definition of 'drama' close to that of E.K. Chambers's 1903 The Medieval Stage, which asserted that dialogue, impersonation, and action are necessary defining characteristics of dramatic activity. ${ }^{48}$ In his study of medieval liturgical processions, however, Roger Reynolds challenges the continued accuracy or efficacy of Chambers's defining criteria as he explores how religious processions could be viewed as constituting dramatic activity in and of themselves, and how processions may have been likely to have incorporated elements of drama. ${ }^{49}$ As noted above, although there is no extant record of scripted drama taking place within an early modern perambulation itself, Reynolds's essay remains useful here as it interrogates those core concepts of mimetic activity and impersonation, and identifies how they could be just as present in liturgical processions. Moreover, it makes a case for paying much greater scrutiny to how processions functioned in relation to drama. This is by no means an unconsidered issue for scholars of early English drama and the relationship between the two aspects of Corpus Christi celebrations - the procession and the play — has been discussed by, among others, Mervyn James and Theresa Coletti..$^{50}$ Likewise, James Stokes examined the processional element in provincial entertainments, including those involving Robin Hood or a summer king. ${ }^{51}$

Broader debates about how customs and ceremonies can be said to have any sense of dramaturgy underpin the specific question of Rogationtide and perambulation festivities in REED collections. Meg Twycross explored this issue in her path-breaking essay on dramatic festivity and processions in which she identified a fundamental link between mimetic activity and performance, the latter concept defined as: 'sustaining a particular kind of behaviour in public for effect'. As she continues: 'This [connection] of course applies to all social events where we are on show, and it could be argued that all formalized public social interaction is in some way mimetic, emphasising a particular facet of our social relationships'.52 Certain kinds of event may be performative without necessarily requiring an audience; indeed, Twycross gives the example of Rogationtide beating the bounds as an 'all-active procession' in which an entire community (as seen above) publicly defined itself and its territory. ${ }^{53}$ 
What are the implications for REED's editors and users if we begin to think with the concept of performance as a distinguishing criterion for consideration and inclusion in a collection, alongside - though not to the exclusion of - mimetic activity? Urban historians have been examining for some time how rituals and ceremonies in late medieval and early modern towns and cities constituted vital forms of performance whereby a community affirmed and celebrated its own identity and integrity, and (to apply Robert Tittler's useful phrase) 'performed or represented itself to itself'. ${ }^{5}$ Rogationtide, however, despite its reflexive communal focus, has hitherto gone without consideration in such studies, as (one might add) has treatment of differences between parish and civic perambulations. Having examined evidence for Norwich's elaborate civic perambulation or 'outriding', and with reconceptions of performative (rather than mimetic) activity in mind, we could make the case for viewing perambulations as occasions of performance and festivity in their own right, and not just as events at which we might find minstrels or waits (as we do in Norwich and Carlisle) or other amusements like the raucous singing recorded at Old Buckenham. This proposal may seem like an interpretative step too far for editors, but there remains an opportunity here for recreating a more three-dimensional, contextually rich understanding of occasions like perambulation day by placing the secular music or singing found in the records within the bigger picture of how a civic community presented itself to itself at Rogationtide.

As indicated above, and underlying the questions posed in this essay, one needs to consider how to acknowledge and record broader non-mimetic performative events like perambulation day within future REED collections. Is this matter merely for an introduction or perhaps an appendix? To return to the example of Norwich's non-Rogationtide civic perambulation: musical accompaniment was a regular feature, as the waits' presence suggests. But does the waits' presence for certain years in the city records indicate they were always an assumed presence? Should a REED editor keep a separate record of when perambulations took place for which there is no explicit reference to musical accompaniment or other activity? How complete a picture of a city or county's festive activity might this yield? One might argue that within the new and evolving format of born-digital REED collections there could be some sort of facility for including longer records records in context and of context - where there is evidence that allows us to reconstruct exceptional festive and performative events. This kind of approach might enable us to place fragmentary allusions to music, singing, or more elaborate activities within an event like perambulation day into a greater, more explanatory — although not necessarily interpretative — whole. While cautious against 
advocating too radical a form of 'mission creep' for REED, this essay has used reflection upon perambulation day to invite editors and users of the project's collections to consider how we might go about recording and analyzing the broader cultures of festivity and performance within which mimetic, musical, and nonmimetic activities took place.

\section{Notes}

As much of the evidence cited above indicates, this article draws in part on research conducted for the revised REED collection for Norwich, 1540-1642. I would like to acknowledge the significant contribution and support made throughout the project by my co-editor Dr Emily Mayne. My gratitude also goes to the UK Arts and Humanities Research Council for funding this project.

1 On the history of Rogationtide and its observation, see Edwin Davenport, 'Elizabethan England's Other Reformation of Manners', English Literary History 63.2 (1996), 260-6, https://doi.org/10.1353/elh.1996.0015; Ronald Hutton, The Rise and Fall of Merry England: The Ritual Year 1440-1700 (Oxford, 1994), 34-6, https:// doi.org/10.1093/acprof:oso/9780198203636.003.0003; M. Bradford Bedingfield, The Dramatic Liturgy of Anglo-Saxon England (Woodbridge, 2002), 191-209; Eamon Duffy, The Stripping of the Altars: Traditional Religion in England, 14001580 (New Haven, 2005), 136-9, 279-80, 426-7, 568; Steve Hindle, 'Beating the Bounds of the Parish: Order, Memory, and Identity in the English Local Community, c. 1500-1700', in Defining Community in Early Modern Europe, ed. Michael J. Halvorson and Karen E. Spierling (Ashgate, 2008), 205-27, https://doi. org/10.4324/9781315258317; Nathan J. Ristuccia, Christianization and Commonwealth in Early Medieval Europe (Oxford, 2018), esp. 24-96, https://doi.org/10.1093/ oso/9780198810209.001.0001.

2 Ristuccia, Christianization, 24-62.

3 Hutton, Rise, 34-6; Duffy, Stripping, 136.

4 Bedingfield, Dramatic Liturgy, 194.

5 Jacobus de Voragine, The Golden Legend: Readings on the Saints, trans. William Granger Ryan (Princeton, 2012), 286-9; Charlotte D’Evelyn and Anna J. Bell, eds, The South English Legendary (London, 1959), 161-2.

6 See, for example, J.L. Glasscock, ed., The Records of St. Michael's Parish Church, Bishop's Stortford (London, 1882), 42-4; John Kitto, ed., St Martin-in-the-Fields 
Churchwardens' Accounts, 1525-1603 (London, 1901), 63, 72, 105, 122, 124; J.C. Cox, Churchwardens' Accounts from the Fourteenth Century to the Close of the Seventeenth Century (London, 1913), 71-2, 263; A.D. Stallard, ed., The Transcript of the Churchwardens' Accounts of the Parish of Tilney All Saints, Norfolk. 1443-1589 (London, 1922), 137, 140, 146, 165, 171, 180.

7 Cox, Churchwardens' Accounts, 71-2.

8 Hindle, 'Beating', 216-18. See also Nicola Whyte, 'Landscape, Memory and Custom: Parish Identities c.1550-1700', Social History 32.2 (2007), 166-86, https://doi. org/10.1080/03071020701245843.

9 Hindle, 'Beating', 218-19; Andy Wood, The Memory of the People: Custom and Popular Senses of the Past in Early Modern England (Cambridge, 2013), 282, https://doi. org/10.1017/CBO9781139034739.

10 Anne Higgins, 'Streets and Markets', in A New History of Early English Drama, ed. John D. Cox and David Scott Kastan (New York, 1997), 83.

11 Duffy, Stripping, 136.

12 George Herbert, The Complete English Poems, ed. John Tobin (London, 1991), 256-7.

13 Duffy, Stripping, 137; Hindle, 'Beating', 213.

14 Lawrence M. Clopper, Drama, Play and Game: English Festive Culture in the Medieval and Early Modern Period (Chicago, 2001), 11-19, 125. Clopper uses 'drama' to mean an enacted script: 'a text and a performance' (19).

15 Arthur F. Leach, ed., Beverley Town Documents (London, 1900), lviii, 112-13. The Beverley Guild Book that records these events forms part of the forthcoming REED collection for Yorkshire, East Riding, edited by Diane Wyatt. The Rogation procession and ridings are referred to in the 1416 Tanners' Orders as an 'old and ancient laudable custom', and they still appear to have been practiced in some form in the mid-sixteenth century; see Leach, ed., Beverley, lviiii; David J.F. Crouch, Piety, Fraternity, and Power: Religious Gilds in Late Medieval Yorkshire 1389-1547 (Woodbridge, 2000), 106.

16 John Brand, Observations on the Popular Antiquities of Great Britain, 3 vols (London, 1849), 1.200; Hutton, Rise, 36.

17 Ristuccia, Christianization, 68-70.

18 Brand, Observations, 1.201-3; Duffy, Stripping, 425-6.

19 W.H. Frere and W.M. Kennedy, eds, Visitation Articles and Injunctions of the Period of the Reformation, 3 vols (London, 1910), 3.15.

20 Hindle, 'Beating', 208.

21 Visitation Articles, 3.264, 3.290, 3.308-9.

22 Hindle, 'Beating', 211-12.

23 Visitation Articles, 3.208, 3.388. 
24 J.F. Williams, ed., Diocese of Norwich: Bishop Redman's Visitation 1597 ([Norwich], 1946), $29,31$.

25 The earliest references are from 1601 at St Peter Mancroft; see Norwich, Norfolk Record Office (NRO), PD 26/71, f 74r. The reference to sugar on perambulation day (1611) is on $\mathrm{f} 104 \mathrm{v}$.

26 Ristuccia, Christianization, 71.

27 These are: Audrey Douglas and Peter Greenfield, eds, REED: Cumberland/Westmoreland/Gloucestershire (Toronto, 1986); James Stokes and Robert J. Alexander, eds, REED: Somerset, 2 vols (Toronto, 1996); James Stokes, ed., REED: Lincolnshire, 2 vols (Toronto, 2009).

28 Stokes, ed., REED: Lincolnshire, 2.454; Stokes and Alexander, eds, REED: Somerset, $1.276,2.752-4$.

29 Douglas and Greenfield, eds, REED: Cumberland, 25-6.

30 John Wasson, ed., REED: Devon (Toronto, 1986), xvii (torchlit perambulations with music for Midsummer eve in Exeter), xix (mayoral perambulation of Plymouth for 'Freedom Day' (21 September)); David Galloway, ed., REED: Norwich, 1540-1642 (Toronto, 1984), 351 (and multiple references to civic perambulations between 1564-1625); Rosalind Conklin Hays and C.E. McGee, eds, REED: Dorset/Cornwall (Toronto, 1999), 412, 439, 455.

31 NRO, NCR 18a/8, f 176v. Evidence of riding of the city bounds dates back much earlier. The Norfolk antiquarian Francis Blomefield noted, for example, that in 1496 the son of sheriff John Pythood fell from his horse and was killed as he rode the bounds that year; see Francis Blomefield, The History of the City and County of Norwich (Norwich, 1745), 129.

32 Galloway, ed., REED: Norwich, 101.

33 Blomefield, History, 192-3.

34 David Underdown, Revel, Riot and Rebellion: Popular Politics and Culture in England, 1603-1660 (Oxford, 1985), 115-16; Hindle, 'Beating', 224-5.

35 Cock vs Jolly (1619), London, National Archives (NA), STAC 8/98/7, mb 3r; transcription by Emily Mayne.

36 Muriel C. McClendon, 'A Moveable Feast: Saint George's Day Celebrations and Religious Change in Early Modern England', Journal of British Studies 38 (1999), 1-27, https://doi.org/10.1086/386179.

37 NRO, NCR 16a/4, f 39v.

38 Carole Rawcliffe, ed., The Norwich Chamberlains' Accounts, 1539-40 to 1544-45 (Norwich, 2019), 46.

39 Norman Davis, ed., Non-Cycle Plays and Fragments (Oxford, 1970), xxxiv-xxxv. 
40 Miri Rubin, Corpus Christi: The Eucharist in Late-Medieval Culture (Cambridge, 1991), 258-62.

41 Ben McRee, 'Religious Gilds and Civil Order: The Case of Norwich in the Late Middle Ages', Speculum 67 (1992), 69-97, https://doi.org/10.2307/2863747; McClendon, 'Moveable Feast'.

42 Keith Thomas, Religion and the Decline of Magic (Harmondsworth, 1971), 62-5.

43 Underdown, Revel, 46, 90-1; Hutton, Rise, 175-6; Hindle, 'Beating'; Wood, Memory, 275-84.

44 Davenport, 'Reformation of Manners', 261.

45 W.S. Trotman, 'Beating the Bounds', Folklore 42.3 (1931), 317-23.

46 Wood, Memory, 279. John Dee records being present throughout the occasion: James Orchard Halliwell, ed., The Private Diary of Dr John Dee (London, 1842), 58.

47 Wood, Memory, 279, 284.

48 E.K. Chambers, The Medieval Stage, 2 vols (Oxford, 1903), 1.vi, 1.188-90.

49 Roger E. Reynolds, 'The Drama of Medieval Liturgical Processions', Revue de musicologie 86.1 (2000), 127-42, https://doi.org/10.2307/947285.

50 Mervyn James, 'Ritual, Drama and the Social Body in the Late Medieval English Town', Past and Present 98 (1983), 3-29, esp. 6, https://doi.org/10.1093/past/98.1.3; Theresa Coletti, 'Reading REED: History and the Records of Early English Drama', in Literary Practice and Social Change in Britain, 1380-1530, ed. Lee Patterson (Berkeley, 1990), 272-81.

51 James Stokes, 'Processional Entertainments in Villages and Small Towns', in Moving Subjects: Processional Performance in the Middle Ages and the Renaissance, ed. Kathleen Ashley and Wim Hüsken (Amsterdam, 2001), 239-257. Ashley's introduction to this volume (7-34), which approaches processions as 'cultural performance', is also relevant to the present discussion. I am grateful to Emily Mayne for this reference.

52 Meg Twycross, 'Some Approaches to Dramatic Festivity, especially Processions', in Festive Drama, ed. Meg Twycross (Cambridge, 1996), 7.

53 Ibid, 10.

54 Robert Tittler, Architecture and Power: The Town Hall and the English Urban Community, c.1500-1640 (Oxford, 1991), 111-12. See also Charles Phythian-Adams, 'Ceremony and the Citizen: The Communal Year at Coventry, 1450-1550', in Crisis and Order in English Towns, 1500-1700, ed. P. Clark and P. Slack (Toronto, 1972), 86-116; James, 'Ritual'; Mary A. Blackstone, 'Walking the City Limits: The Performance of Authority and Identity in Mary Tudor's Norwich', in Shakespeare and Religious Change, ed. Kenneth Graham and Philip Collington (Basingstoke, 2009), 106-38; Barbara A. Hanawalt, Ceremony and Civility: Civic 
Culture in Late Medieval London (Oxford, 2017), esp. 139, https://doi.org/10.1093/ oso/9780190490393.001.0001. 
